\author{
Marta Maier*
}

\title{
SYTUACJA OSÓB W WIEKU 50+ NA RYNKU PRACY W POLSCE
}

Z a r y s t r e ś c i: Obecnie do najistotniejszych problemów rynku pracy w Polsce zaliczyć należy starzenie się zasobów pracy. Wynika to z rosnącego odsetka osób starszych w populacji, będącego konsekwencją niskiego wskaźnika urodzeń oraz wydłużenia przeciętnego trwania ludzkiego życia.

Celem artykułu jest zaprezentowanie wpływu zmian demograficznych na sytuację na rynku pracy pracy w Polsce, ze szczególnym uwzględnieniem pokolenia 50+ oraz konsekwencji, jakie zmiany te powodują. Dodatkowo przedstawione zostaną czynniki determinujące sytuację osób starszych na rynku pracy, a także polityka rynku pracy względem tej grupy społecznej.

S ło w a k 1 u c z o w e: rynek pracy, zmiany demograficzne, starzenie się społeczeństwa.

K 1 a s y fik a c j J E L: L 21

\section{WSTĘP}

Zjawisko starzenia się społeczeństwa związane ze spadkiem liczby urodzeń przy jednoczesnym wydłużaniu ludzkiego życia to problemy, z jakimi obecnie musi zmierzyć się rynek pracy w Polsce. Co więcej, w ramach niekorzystanych zmian demograficznych występuje także spadek dzietności, wzrost średniego wieku kobiet decydujących się na rodzenie dzieci, spadek umieralności oraz wzrost udziału osób starszych w ogólnej liczbie ludności. Zmiany, jakie zachodzą w strukturze demograficznej państwa niosą zatem za sobą konsekwencje o charakterze społeczno-gospodarczym, tj. nasilenie procesu dezaktywacji

\footnotetext{
* Adres do korespondencji: Marta Maier, Politechnika Gdańska, Wydział Zarządzania i Ekonomii, Katedra Analizy Ekonomicznej i Finansów Publicznych, ul. Traugutta 79, 80-233 Gdańsk, e-mail: marta_maier@poczta.onet.pl;
} 
zawodowej osób starszych i związany z tym wzrost wydatków na zabezpieczenie społeczne. Głównymi czynnikami, które decydują o wycofaniu się osób starszych z rynku pracy są przede wszystkim względy finansowe, czyli relacja wysokości pobieranej emerytury do ewentualnego otrzymywanego wynagrodzenia, a także stan zdrowia czy obowiązujące wśród pracodawców stereotypy, że starszy pracownik to pracownik mniej wydajny.

Dodatkowo prowadzona przez państwo polityka rynku pracy nie zachęca do pozostawania aktywnym zawodowo do późnych lat starości. Rzeczywisty przełom w postrzeganiu osób starszych jako potencjalne, niewykorzystane zasoby pracy nastąpił dopiero po 2004 r., kiedy to zmiany demograficzne zaczęto traktować w kategorii zagrożenia dla rynku pracy. Efektem tych zmian było wprowadzenie szeregu programów skierowanych do osób starszych. Większą uwagę zaczęto także przykładać na kwestie związane z zarządzaniem wiekiem oraz pozycji, jaką osoby starsze zajmują $\mathrm{w}$ ramach struktury organizacyjnej danego przedsiębiorstwa.

Z perspektywy ekonomicznej starzenie się społeczeństwa to zwiększenie obciążeń związanych z kosztami pracy, w konsekwencji powodujące zmniejszenie zdolności przedsiębiorców do tworzenia nowych miejsc pracy [Błaszczyk, 2016, s. 51-52]. Zjawisko starzenia się zasobów pracy ma bowiem wpływ na zmniejszenie mobilności pracowniczej. Osoby starsze charakteryzują się bowiem niską mobilnością zawodową, przestrzenną czy międzyzakładową, co prowadzi do zmniejszenia elastyczności reagowania na zmiany, jakie zachodzą na rynku pracy. Społeczne skutki starzenia się społeczeństwa związane są przede wszystkim z marginalizacją i wykluczeniem osób starszych ze społeczeństwa.

Celem niniejszego artykułu jest zaprezentowanie czynników mających wpływ na sytuację osób starszych na rynku pracy w Polsce oraz polityki rynku pracy względem tej grupy społecznej. Warto bowiem zastanowić się, w jakim stopniu zmiany demograficzne determinują sytuację, jaka obecnie ma miejsce na rynku pracy oraz jaki wpływ zmiany te będą miały na przyszłość osób starszych. Doprecyzowania w tym przypadku wymaga samo stwierdzenie „osoby starsze”. Należy przyjąć, że osobą starszą na rynku pracy jest ta powyżej 50. roku życia, czyli zaliczana do osób w wieku niemobilnym. Są to osoby, które nie są chętne do zmiany miejsca pracy, dokształcania się czy przekwalifikowania, celem zmiany stanowiska pracy. To wówczas zaczyna się okres tzw. stabilizacji. Z uwagi na powyższe $\mathrm{w}$ artykule przedstawiona zostanie sytuacja osób 50+ na rynku pracy w Polsce.

\section{ZMIANY DEMOGRAFICZNE W POLSCE}

Zjawisko starzenia się społeczeństwa w Polsce zapoczątkowane zostało przejściem demograficznym polegającym na zmianie reżimu reprodukcji po- 
pulacji z modelu tradycyjnego na nowoczesny, gdzie dominującym zjawiskiem była niska stopa zgonów i urodzeń. Przeobrażenia te doprowadziły do zmiany w ramach struktury wiekowej ludności Polski.

Ostatnie ćwierćwiecze to okres spowolnienia rozwoju demograficznego państwa. Główną przyczyną tego działania była intensyfikacja proces starzenia się społeczeństwa, będącego wynikiem wydłużenia przeciętnego trwania ludzkiego życia, niskiego poziomu dzietności oraz emigracji młodych ludzi. Cechą charakterystyczną gospodarki Polski jest przede wszystkim wydłużanie się ludzkiego życia [Jóźwiak, 2013, s.9]. Dodatkowo, utrzymująca się niska stopa urodzeń i niski współczynnik dzietności, który nie umożliwia zachowania prostej zastępowalności pokoleń (wartość współczynnika poniżej 1,3) to problemy z jakimi zmierzyć musi się Polska.

Poprawa stanu zdrowia wynikająca z postępu medycyny i większej dbałości o kondycję zawodową miała bezpośrednie przełożenie na spadek liczby zgonów i jednoczesne wydłużenie przeciętnego trwania ludzkiego życia.

Wykres 1. Przeciętne trwanie życia kobiet i mężczyzn w Polsce w latach 2000-2015

\section{Przeciętna długość trwania życia kobiet i mężczyzn w Polsce w latach 2000- 2015}

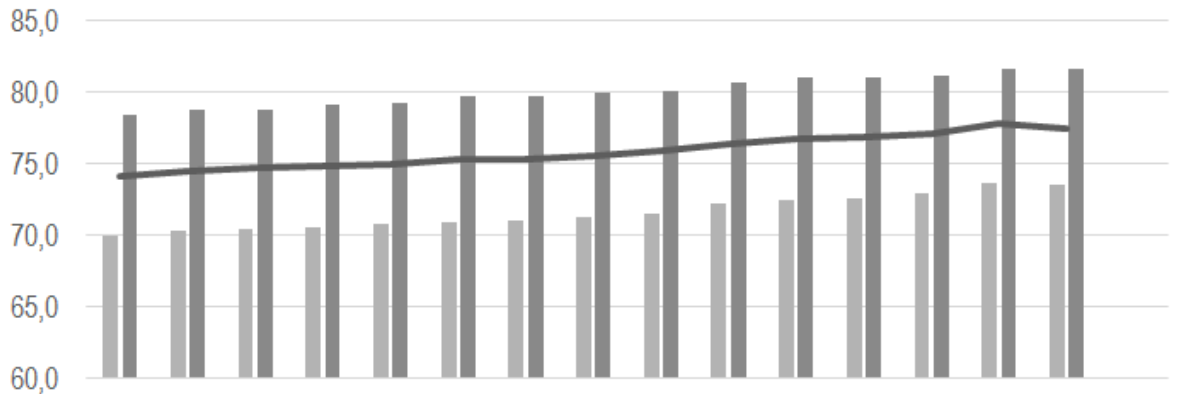

200120022003200420052006200720082009201020112012201320142015

Mężczyźni Kobiety —

Przeciętne trwanie życia wzrosło o ok. 0,7 roku - do 73,8 lat dla mężczyzn i ok. 0,5 roku - do 81,6 lat dla kobiet. Doszło tym samym do zmniejszenia różnicy między długością życia obu płci. 
Wykres 2. Liczba urodzeń żywych w Polsce w latach 2004-2015

Liczba urodzeń żywych w Polsce w latach 2004-2015

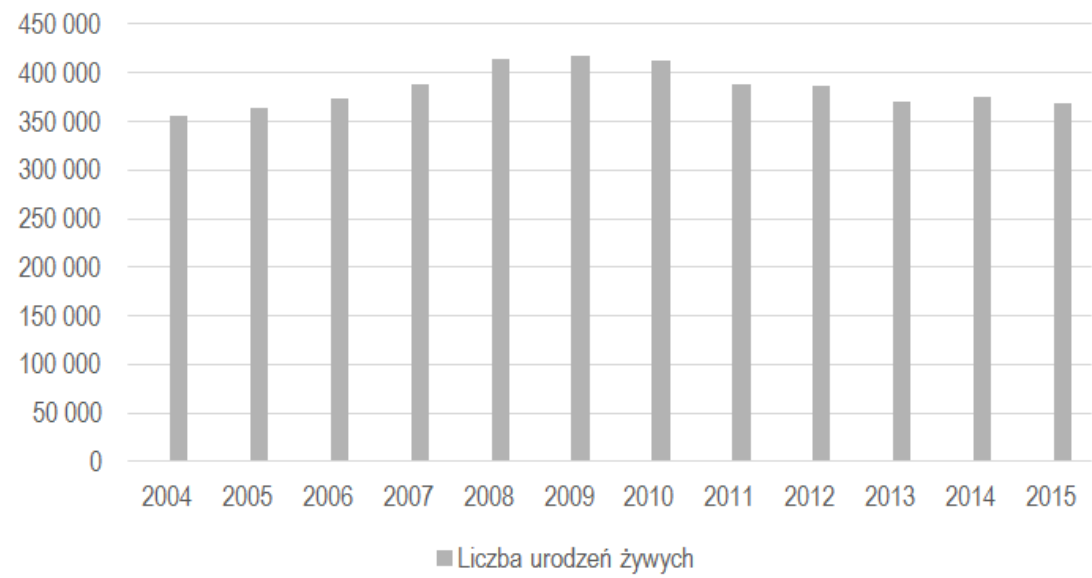

W 2010 r. liczba urodzeń żywych wynosiła w Polsce 410 tys., w kolejnych latach ulegała spadkowi, osiągając w 2016 r. wartość 369 tys. Główną przyczyną spadku liczby urodzeń było obniżenie poziomu płodności kobiet, który dodatkowo wspomagany był przez zmiany w strukturze wieku rozrodczego kobiet oraz zmianą obowiązującego wzorca rodziny.

Starzenie się ludności to zjawisko, które polega na zwiększeniu odsetka osób starszych przy jednoczesnym zmniejszeniu odsetka dzieci w całej populacji.

Wykres 3. Udział osób w wieku 50+ w Polsce w latach 2000-2015

\section{Udział osób w wieku 50+ w Polsce w latach 2000-2015}

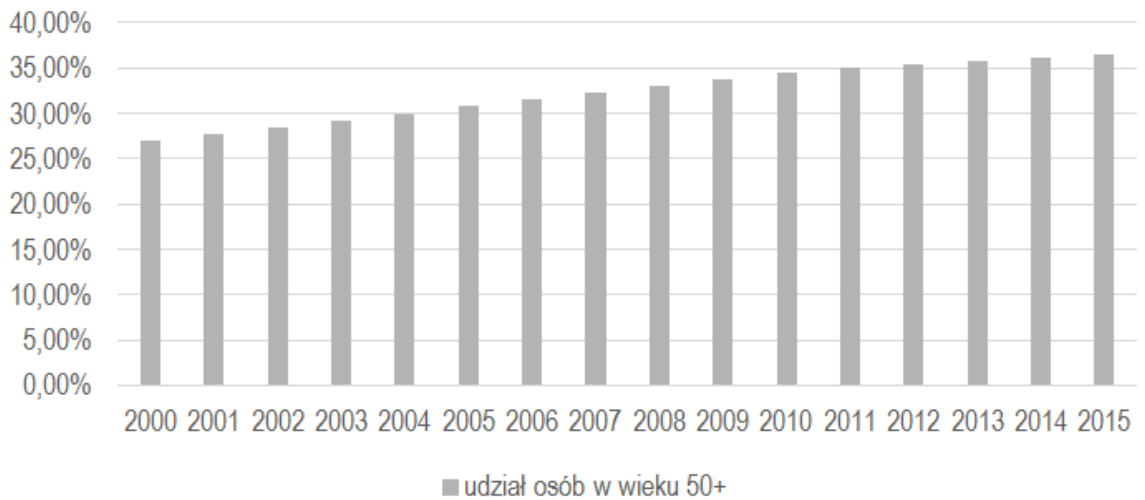


Prognozy demograficzne dotyczące roku 2060 jednoznacznie wskazują, że udział osób starszych w ogólnej liczbie ludności wzrośnie do ok. 35\%, a potencjalne zasoby pracy mogą zmniejszyć się nawet o $10 \mathrm{mln}$ [Eurostat].

Proces starzenia się ludności prowadzi do zmniejszenia zasobów siły roboczej, powodując jednocześnie wzrost obciążenia osób w wieku produkcyjnym ludnością w wieku poprodukcyjnym. Wczesna dezaktywacja zawodowa osób starszych prowadzi do sytuacji niewykorzystania istotnej części zasobów pracy, jakie występują w gospodarce państwa. Moment opuszczenia rynku pracy utożsamiany jest dodatkowo z zaprzestaniem dalszej aktywności zawodowej, zwiększając tym samym współczynnik obciążenia demograficznego.

Wykres 4. Ekonomiczne grupy wiekowe w Polsce w latach 2000-2015

\section{Liczba ludności w Polsce z podziałem na ekonomiczne grupy wiekowe w} latach 2000-2015

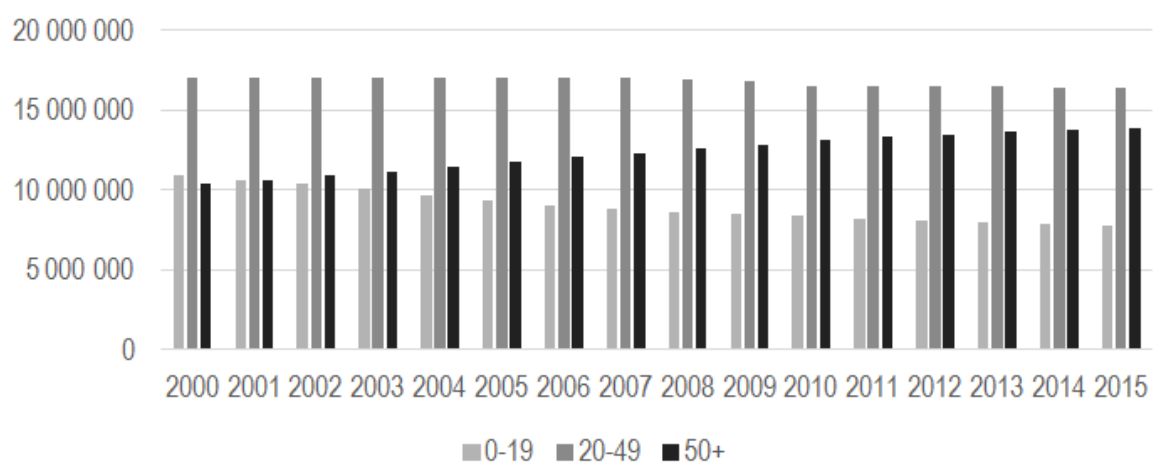

Wydłużanie się przeciętnego trwania życia bezpośrednio prowadzi do zmiany w strukturze wieku ludności Polski, co w efekcie powoduje starzenie się zasobów pracy oraz zwiększenie udziału osób starszych w ogólnej populacji. Dodatkowym negatywnym skutkiem tych przemian występującym na rynku pracy jest kurczenie się zasobów pracy. Proces starzenia się społeczeństwa ma zatem bezpośrednie przełożenie na spadek liczby ludności w wieku produkcyjnym. Charakterystyczne zatem staje się systematyczne starzenie się potencjalnych zasobów pracy, czyli wzrost liczby osób w wieku niemobilnym.

\section{SYTUACJA OSÓB 50+ NA RYNKU PRACY W POLSCE}

Pokolenie 50+ to osoby, które ukończyły 50 lat, jednakże nie osiągnęły wieku emerytalnego. Charakteryzują się relatywnie złym stanem zdrowia, mają również większe problemy ze znalezieniem pracy. Problemy te dodatkowo po- 
głębiane są rosnącymi wymaganiami płacowymi, jak i koniecznością zdobywania doświadczenia i stażu pracy [Rembiasz, 2013, s. 337].

W przypadku starzenia się zasobów pracy ważnym czynnikiem staje się zarządzanie wiekiem w przedsiębiorstwie, które traktować należy jako jeden z głównych elementów zarządzania zasobami ludzkimi oraz kształtowanie relacji między pracodawcą a osobami starszymi, tak by w pełni móc wykorzystać potencjał, jakim dysponuje ta grupa społeczna.

Pokolenie 50+ często określa się mianem osób skrupulatnych i dokładnych, posiadających doświadczenie zawodowe i duży zasób wiedzy przez co w wielu sytuacjach traktowani są jako mentorzy, wzorce odgrywające określone role społeczne. Co więcej są grupą społeczną, która znacznie rzadziej korzysta ze zwolnień lekarskich w stosunku do młodych pracowników, nie blokuje miejsc pracy z powodu urlopów macierzyńskich czy wychowawczych, jednakże są mniej asertywni niż młodsze pokolenie. $Z$ drugiej strony osoby starsze jako grupa społeczna cechują się także pewnymi wadami, do których zaliczyć należy przede wszystkim mniejszą wydajność i wolniejsze tempo pracy, słabszą znajomość języków obcych, brak swobody w korzystaniu z nowych technologii, znacznie mniejszą kreatywność w wykonywaniu czynności służbowych. Dodatkowo z uwagi na zbliżającą się emeryturę mówi się o nieopłacalność w inwestowanie w tę grupę społeczną.

Polska przez wiele lat borykała się z problemem zbyt wczesnej dezaktywacji zawodowej występujących w gospodarce zasobów pracy. Panował bowiem pogląd, że osoby starsze posiadają stosunkowo niskie kwalifikacje zawodowe, są mało mobilne i nie do końca rozumieją zasady, na podstawie których funkcjonuje gospodarka rynkowa. Dodatkowo osoby te zainteresowane były szybkim opuszczeniem rynku pracy i przejściem na emeryturę, rentę lub korzystanie z innego świadczenia społecznego. W dużej mierze podejście to zostało utrzymane do dnia dzisiejszego [Błędowski, Warszawa, s.54], jednakże uwarunkowania zewnętrzne wynikające $\mathrm{z}$ reformy emerytalnej oraz uniemożliwieniu przejścia na wcześniejszą emeryturę doprowadziły do zmniejszenia procesu dezaktywacji zawodowej. Należy zauważyć, że osoby w wieku 50+ coraz chętniej podejmują zatrudnienie w ramach elastycznych form zatrudnienia ${ }^{1}$.

W ramach aktywności zawodowej osób starszych wyróżnia się dwa główne podejścia, czyli „retirement push” i „pull factors”. Są to czynniki, które kolejno przyciągają osoby starsze do przejścia na emeryturę oraz czynniki, które traktować należy jako pewne utrudnienie w znalezieniu i co więcej utrzymaniu zatrudnienia, tym samym wypychając je z rynku pracy - najczęściej są to czynniki o charakterze ekonomicznym [Live longer, work longer, 2006].

\footnotetext{
${ }^{1} \mathrm{Wg}$ badania „Wpływ elastycznych form zatrudnienia i organizacji pracy na aktywność zawodową zasobów pracy w wieku 50+" IPiSS
} 
Kolejnym czynnikiem decydującym o „wypchnięciu” osób starszych z rynku pracy jest niski poziom wykształcenia. Kompetencje, jakie posiadają osoby w wieku 50+ często określa się mianem przestarzałych, co utrudnia możliwość utrzymania się na rynku pracy (potwierdzeniem tego jest fakt, że Polska zaliczana jest do państw o najniższym poziomie uczestnictwa w kształceniu ustawicznym osób starszych, w stosunku do państw UE).

Stan zdrowia to następny, ważny element decydujący o wycofaniu się z rynku pracy osób starszych. Problemy zdrowotne osób w wieku 50+ bardzo się nasilają, następuje pogorszenie stanu zdrowia oraz wzrost niepełnosprawności, co prowadzi do wycofania tych osób z aktywności zawodowej.

Czynniki społeczne determinują również sytuację osób starszych na rynku pracy. Jednym z nich jest niechęć starszego pokolenia do pozostawiania na rynku pracy do późnych lat, dodatkowo panujące stereotypy postrzegania osób starszych przez pracodawców jako pracowników gorszych i mniej wydajnych. Często można spotkać się ze stwierdzeniem, że osoby po 50. roku życia należy zaliczyć do grupy pracowników, która jest zagrożeniem dla konkurencyjności firmy, co prowadzi do osłabienia jej pozycji rynkowej, bowiem starsi pracownicy posiadają przestarzałe kwalifikacje, a dodatkowo nie są chętni do ewentualnego przeszkalania, niechętnie podejmują się uczenia nowych umiejętności, reprezentują postawę konserwatywną, mają problemy z nowymi technologiami. Stereotypy te prowadzą do dyskryminacji tej grupy społecznej, potęgując akceptację do wcześniejszej rezygnacji z bycia aktywnym zawodowo [Urbaniak, 2008 , s.12].

Polityka rynku pracy w Polsce utrudnia i tak już niekorzystną sytuację osób starszych na rynku pracy. Początkowo celem polityki rynku pracy była wcześniejsza dezaktywizacja osób starszych (początek lat 70.), która traktowana była jako pewnego rodzaju przywilej. Z jednej strony umożliwiano osobom starszym przejście na wcześniejszą emeryturę i opuszczenie rynku pracy, z drugiej strony osobom już pobierającym świadczenia emerytalne, stworzono dodatkową motywację do pracy. Zasadniczy zwrot w stosowaniu polityki rynku pracy względem osób starszych nastąpił w 2004 r., w momencie wprowadzenia ustawy z 20.04.2004 r. o promocji zatrudnienia i instytucjach rynku pracy [DzU z 2004 r., nr 99, poz.1001], w której to szczególną uwagę przypisano osobom starszym znajdującym się w trudnej sytuacji na rynku pracy. Dopiero nacisk ze strony Unii Europejskiej spowodował potrzebę wprowadzenia zmian w ramach polityki rynku pracy, przede wszystkim z uwagi na zagrożenie zmian demograficznych, które mają bezpośredni wpływ na gospodarkę państwa.

Lata dziewięćdziesiąte to okres, w którym liczba osób w wieku produkcyjnym stale rosła, jednakże tempo przyrostu jest z każdym kolejnym rokiem coraz wolniejsze (do 2050 r. liczba osób w wieku produkcyjnym ma zmniejszyć się o ok. 6 mln osób). Równolegle następuje proces starzenia się społeczeństwa, 
czyli wzrost liczby osób w wieku niemobilnym tj. 50+. Tendencja ta zachować ma się aż do 2060 r. [Rocznik demograficzny GUS, 2015, s.39].

Uwzględniając prognozy demograficzne należy zwrócić szczególną uwagę na dążenie do utrzymania jak największej aktywności zawodowej osób starszych. W Polsce wskaźnik zatrudnienia osób w wieku 50+ utrzymuje się na poziomie 46,9\% w 2015 r., natomiast współczynnik aktywności zawodowej na poziomie $42,5 \% \mathrm{w} 2015 \mathrm{r}$.

Wykres 5. Wskaźnik zatrudnienia osób w wieku 50+ w Polsce w latach 2000-2015

\section{Wskaźnik zatrudnienia osób 50+ w Polsce w latach 2000-2015}

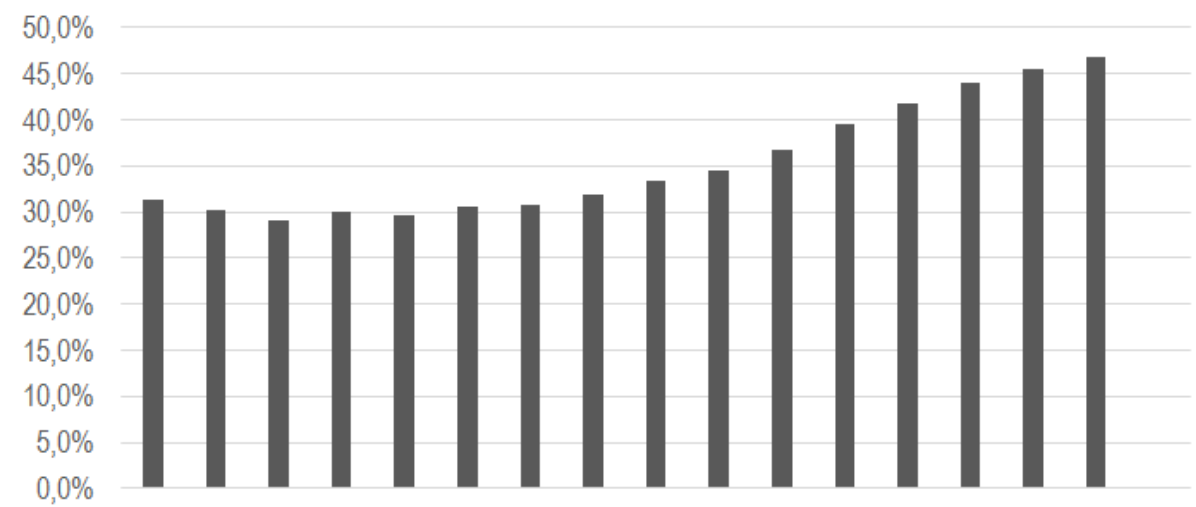

2000200120022003200420052006200720082009201020112012201320142015

Polska należy do państw o niskim poziomie wskaźnika zatrudnienia osób powyżej 50. roku życia. Mimo to stopa zatrudnienia osób w wieku 50+ w Polsce w latach 2000-2015 uległą zwiększeniu z 31\% do 46,9\%, a więc o 15,6 punktu procentowego. Poziom stopy zatrudnienia osób starszych jest ściśle związany z przeciętnym wiekiem wyjścia ze zbiorowości czynnych zawodowo do zbiorowości biernych zawodowo.

Współczynnik aktywności zawodowej osób powyżej 50. roku życia w 2005 r. wyniósł ok. 35\%, co oznacza niewielki wzrost, bo zaledwie o 0,6 p.p. względem kolejnych lat. Oznacza to, że średnio co trzecia osoba w grupie $50+$ jest nadal aktywna zawodowo. Mimo stałej poprawy wskaźnika opisującego sytuację osób starszych na rynku pracy nadal odbiega on od średniej unijnej, choć warto zauważyć, że różnica ta nie jest już tak duża jak kilka lat temu (GUS, 2016, s. 1-3). 
Wykres 6. Współczynnik aktywności zawodowej osób w wieku 50+ w Polsce w latach 2000-2015

\section{Współczynnik aktywności zawodowej osób w wieku 50+ w Polsce w latach 2000-2015}

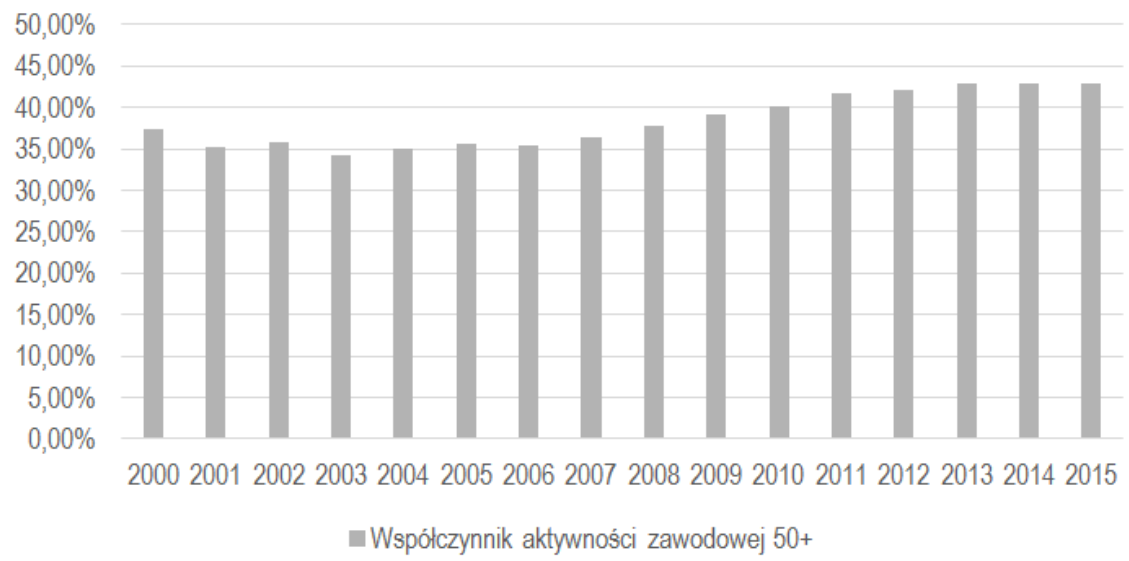

W obliczu niesprzyjających warunków na rynku pracy aktywność zawodowa osób starszych oraz zatrudnienie osób 50+ systematycznie wzrasta, choć jest to proces powolny. Oznacza to, że wzrost liczby pracujących ogółem w ostatnich latach miał bezpośrednie przełożenie na wzrost liczby pracujących w starszych grupach wiekowych.

\section{PODSUMOWANIE}

Precyzyjne określenie „osoby starszej” jako uczestnika rynku pracy jest dość kłopotliwe. Starzenie się traktować należy bowiem jako proces o charakterze wielopłaszczyznowym, mającym uwarunkowania zarówno społeczne, jak i ekonomiczne.

Najbliższe kilkanaście lat to czas nieodwracalnych zmian na rynku pracy w Polsce w związku ze zmianami demograficznymi. Utrzymanie aktywności zawodowej osób starszych może w znacznym stopniu zmniejszyć obciążenia budżetu państwa z tytułu świadczeń i ubezpieczeń społecznych, co więcej będzie szansą na tworzenie miejsc pracy skierowanych do młodych ludzi.

Ważną kwestią w dążeniu do równoważenia problemów zawodowych, z jakimi spotykają się osoby starsze jest pełne wykorzystanie dostępnych instrumentów w ramach poprawy elastyczności i bezpieczeństwa na rynku pracy. Problemy osób starszych na rynku pracy traktować należy poważnie, gdyż obecny poziom aktywności zawodowej tej grupy społecznej zalicza się do jednego 
z najniższych w Europie. Ponadto osoby w wieku 50+ zaliczane są do osób silnie znudzonych pracą o dużym nastawieniu na szybkie przejście na emeryturę. Tak istotne staje się zatem stworzenie w najbliższej przyszłości spójnej polityki państwa, której celem będzie nastawienie na aktywizację zawodową starszego pokolenia oraz przełamywanie stereotypów dotyczących starszych pracowników.

Zjawisko starzenia się zasobów pracy to problem, z jakim obecnie zmierzyć musi się polski rynek pracy. Coraz pilniejsza staje się tutaj potrzeba dążenia do zwiększenia aktywności zawodowej osób starzejących się. Potrzeba ta zauważona została również w ramach prowadzonej przez państwo polityki rynku pracy. Dodatkowo dużą rolę powinna odgrywać edukacja ustawiczna, która jest jednym z podstawowych czynników, decydujących o rozwoju współczesnych społeczeństw, ułatwiając sprostanie wyzwaniom nowych technologii czy przemianom w ramach demokratyzacji życia społecznego. Podnoszenie kwalifikacji zawodowych i kompetencji staje się drogą umożliwiającą utrzymanie się na rynku pracy osób starszych.

Współcześnie zmiany struktury demograficznej ludności przyjmują strategiczny stosunek względem procesów, jakie zachodzą na rynku pracy, jednocześnie je determinując oraz wyznaczając ich dalszy przebieg. Najistotniejsze znaczenie ma tutaj zjawisko starzenia się społeczeństwa charakteryzujące się tendencją do ciągłego pogłębiania się.

Rosnące znaczenie osób starszych jako uczestników rynku pracy związane jest przede wszystkim z zachodzącymi zmianami społeczno-ekonomicznymi. Zwiększenie udziału tej grupy wiekowej w społeczeństwie wymaga podjęcia odpowiednich kroków, by w pełni wykorzystać potencjał osób starszych.

W Polsce zaobserwowano istotne dla gospodarki narodowej zmiany, które wynikają z przeobrażeń struktury demograficznej ludności. Zmiany demograficzne w istotny sposób oddziaływują na rynek pracy i wymagają podjęcia działań zmierzających do zwiększenia aktywności zawodowej ludności. Wydłużenie okresu aktywności zawodowej osób starszych staje się zatem nieuniknione i działania takie powinny być uwzględnione w polityce makroekonomicznej państwa.

\section{LITERATURA}

Błaszczyk B., (2016), Sytuacja osób starszych na rynku pracy w Polsce, Gerontologia Polska 2016.

Błędowski P., (2013), Aktywność zawodowa osób w starszym wieku. [w:] Kiełkowska M. (red.). Rynek pracy wobec zmian demograficznych. Zeszyty Demograficzne. Warszawa: Instytut Obywatelski.

Borowiec A., Rembiasz M., (2014), Pokolenie 50+ na rynku pracy - wybrane problemy, [w:] M. Szczepański, T. Brzęczek, M. Gajowiak (red.), Systemy zabezpieczenia społecznego wobec wyzwań demogra cznych i rynkowych, Wydawnictwo Politechniki Poznańskiej, Poznań. 
DzU z 2004 r., nr 99, poz.1001 o promocji zatrudnienia i instytucjach rynku pracy.

Jóźwiak J., (2013), Demograficzne uwarunkowania rynku pracy w Polsce, [w:] M. Kiełkowska (red.), Rynek pracy wobec zmian demograficznych, Instytut Obywatelski, Warszawa.

MillwardBrown SMG/KRC, (2011), Raport z badań Kompleksowy program aktywizacji osób starszych 50+, Warszawa.

Rembiasz M., (2013), Aktywność zawodowa osób w wieku emerytalnym - wybrane problemy, [w:] Szczepański M., (red.), Reformowanie systemów emerytalnych - porównania i oceny, Wydawnictwo Politechniki Poznańskiej, Poznań.

Rocznik demograficzny GUS, 2015.

Schimanek T., (2006), Sytuacja osób powyżej 50-tego roku życia na rynku pracy oraz rola organizacji pozarzadowych świadczacych ustugi rynku pracy skierowane do tych osób, FISE, Warszawa.

Urbaniak B., (2014), Starsi pracownicy na rynku pracy, [w:] Pracownicy po 45 roku życia wobec barier na rynku pracy, Dom Wydawniczy Elipsa, Warszawa.

\title{
DEMOGRAPHIC CHANGES IN THE LABOUR MARKET IN POLAND IN THE CONTEXT OF PERSONS 50+
}

\begin{abstract}
Nova days, the most important issues of the labor market in Poland covers aging of labor resources. This is due to the growing proportion of elderly people in the population, caused with low birth rate and prolonged life expectancy year-on-year.

The aim of this article is to highlight the impact of demographic changes on the labor market in Poland, mostly focused on 50+ generation and the consequences that these changes cause.
\end{abstract}

Keywords: labor market, demographic change, aging population. 
